\title{
Investor reaction to strategic emphasis on earnings numbers: An empirical study
}

\author{
M. Shibley Sadique', M. Arifur Rahman²
}

ABSTRACT

\begin{abstract}
We analyze the earnings information and stock prices of S\&P500 firms and find that investors following S\&P500 stocks (i) respond more to pro forma earnings than to GAAP earnings, (ii) respond to an emphasis on pro forma earnings, and (iii) are fixated on pro forma earnings. We provide the first direct evidence that a strategic emphasis on earnings numbers may affect return volatility. Further, our results do not support the argument that a larger investor response to Street earnings might be driven by large differences between the Street numbers and GAAP numbers.
\end{abstract}

KEY WORDS: $\quad$ earnings press release; emphasis on earnings numbers; stock market reaction; functional fixation hypothesis; fourth quarter earnings

JEL Classification: $\quad$ G11; G14; M41

${ }^{1}$ Curtin University, Malaysia, ${ }^{2}$ Universiti Brunei Darussalam, Brunei Darussalam

\section{Introduction}

This study examines whether a strategic emphasis on earnings numbers in company press releases has any impact on stock returns. We define strategic emphasis as emphasis on one earnings number over another or the exclusion of an earnings number from a press release with the purpose of painting a rosy picture of a firm's financial position. Given that a vast amount of information is constantly flowing into the market, it is very difficult for even astute investors to sift through such an information flow in an organized manner. Indeed, departing from the traditional analytical modeling of financial reporting that assumes investor rationality and market efficiency with respect to public information, Hirshleifer and Teoh (2003) show that, due to limited investor attention and information processing capacity, informationally equivalent

Correspondence concerning this article should be addressed to: M. Shibley Sadique, Curtin University, Sarawak Malaysia, CDT 250, 98009 Miri Sarawak, Malaysia, e-mail: shibley@curtin.edu.my disclosures can have very different effects on investor perceptions, depending on the form of presentation. Other theoretical studies, such as that of Bloomfield (2002), also suggest that companies can influence investors' judgment by putting earning numbers in a prominent place (headline or lead paragraph) in a press release or by burying them somewhere in a less prominent position. Therefore, it is important to examine whether there is any informational value in emphasizing a preferred earnings metric in companies' press releases. Obviously, investors form expectations, at least partially, about the stocks they follow on the basis of what they read in the earnings press releases.

Companies' earnings press releases usually include two types of earnings numbers: GAAP (Generally Accepted Accounting Principles) earnings and pro forma earnings (popularly known as Street earnings). For GAAP earnings, specific rules are followed to calculate earnings, whereas pro forma earnings are often defined by companies and calculated without following any standard rules. However, the purposeful exclusion 
of certain items from pro forma earnings (e.g., nonrecurring transitory items) is possible in earnings press releases because they are not subject to the SEC's (Securities and Exchange Commission) scrutiny unless they are fraudulent.

Bradshaw and Sloan (2002) provide compelling evidence of managers' tendency to emphasize Street earnings because they present the Street earnings earlier than the GAAP earnings in press releases. The authors relate the tendency of managers to report higher Street numbers to a firm's effort to achieve higher valuations. Subsequently, studies have identified at least four specific reasons why firms emphasize pro forma earnings over GAAP earnings in their reports. First, firms deliberately report pro forma earnings when their earnings and stock prices start to decline (Bhattacharya, et al., 2004). Second, firms with greater incidences of losses, higher leverage, and higher proportions of special items tend to report pro forma earnings (Lougee and Marquardt, 2004). Third, firms may manipulate earnings to meet or beat analysts' expectations (Doyle, McNichols, \& Soliman, 2013). Finally, senior executives may try to use discretionary components of earnings to inflate a firm's reported earnings and thus its stock price because their compensation packages are tied to the company stock price (Bergstresser \& Phillippon, 2006). Empirical evidence also shows that stock returns around earnings announcement days are more responsive to pro forma earnings than to GAAP earnings (Bhattacharya, et al., 2003; Brown \& Sivakumar, 2003). Bowen, Davis and Matsumoto (2005) find that a strategic emphasis on an earnings metric (pro forma or GAAP) affects stock market participants, and firms with more media exposure place a greater emphasis on pro forma earnings than on GAAP earnings.

Relatedly, from a behavioral accounting perspective, the functional fixation hypothesis of Hand (1990) suggests that individual investors do not consider the quality of earnings. Experimental research on financial information processing also suggests that the market mechanically capitalizes reported earnings numbers without adjusting for the quality of the earnings (Libby, Bloomfield, \& Nelson, 2002). According to Hirshleifer and Teoh (2003), limited attention provides a motivation for such functional fixation on the part of the investors. If the functional fixation holds, a pro forma disclosure may cause investors to perceive an earnings announcement as more favorable, which, in turn, causes them to expect a higher stock price in the period around such an announcement.

When companies tend to purposefully emphasize pro forma earnings and investors care only about the earnings numbers without paying much attention to the underlying accounting procedures and/or have limited information processing capacity, then a thorough analysis of the emphasis on a particular earnings metric becomes an issue of obvious importance to investors and market regulators. In our effort to assess the informational value of a strategic emphasis on earnings numbers, we analyze the earnings information and stock prices of S\&P500 firms and address the following three research questions in this paper:

a Does a deliberate emphasis on a particular earnings number in company press releases attract a shareholder's attention and affect stock prices? As long as firms use a strategic emphasis and investors perceive pro forma earnings as more value relevant, we should find a positive relationship between returns and such an emphasis unless investors identify that such an emphasis is completely opportunistic. Accordingly, we conjecture that return responses to a pro forma earnings emphasis will be greater than the return responses to a GAAP emphasis.

b Does a managerial emphasis in earnings disclosures affect the volatility of stock returns? Ideally, the very purpose of earnings disclosures in company press releases in general is to accelerate the resolution of investor uncertainty. Accordingly, in the wake of a current period's earnings press release, we would normally expect to observe a decline in uncertainty as measured by the volatility of stock returns. However, an alternative possibility is that an opportunistic emphasis on earnings numbers may magnify the information asymmetry among market participants associated with an earnings surprise and thereby increase the volatility of returns, at least in the short run (see, for example, Kim \& Verrecchia, 1994). It is also not unlikely that investors' uncertainty about intrinsic firm value increases because of a deliberate emphasis placed on a particular earnings number.

c Are investors really fixated on pro forma earnings? The functional fixation hypothesis (Hand, 1990) posits that investors are fixated on an earnings 
Table 1. Sample selection criteria (S\&P500).

\begin{tabular}{|c|c|}
\hline Panel A-initial sample & \\
\hline & Number of firms \\
\hline Initial sample & 500 \\
\hline \multicolumn{2}{|l|}{ Less: } \\
\hline $\begin{array}{l}\text { Firms dropped because fewer than } 16 \text { quarters of firm-issued earnings press } \\
\text { releases are available }\end{array}$ & $(192)$ \\
\hline \multicolumn{2}{|l|}{ Panel B-final sample } \\
\hline & Number of observations \\
\hline Final sample (308 firms) & 8316 \\
\hline \multicolumn{2}{|l|}{ Less: } \\
\hline Firm-issued earnings press releases not available & $(1816)$ \\
\hline No strategic emphasis in earnings $\left(E P S_{\text {Pro forma }}=E_{\text {GAAP }}\right)$ & $(978)$ \\
\hline Observations included in the final sample & 5522 \\
\hline
\end{tabular}

Notes:

This table shows the selection of the final sample used in this study.

metric, and they do not adjust for earnings quality. On the contrary, however, Abarbanell and Lehavy (2007) show that studies using Street earnings supplied by the Institutional Brokers' Estimate System (IBES) as a proxy for pro forma earnings and Compustat-provided GAAP earnings may erroneously support the idea that investors are more responsive to Street earnings. The authors claim that the findings supporting the fixation hypothesis may reflect frequently observed large differences between Street and GAAP earnings. We verify whether the claim against the functional fixation hypothesis is confirmed by our data.

Although our study is similar in some respects to that of Bowen at al. (2005), our study can be considered an expanded analysis of a strategic emphasis on earnings metrics in the following contexts. First, our study examines the impact of an emphasis on earnings numbers on volatility in addition to stock returns. Prior empirical studies have examined only stock return response to a strategic earnings emphasis. Stock return volatility is an important risk factor to consider in investors' portfolio management decisions. Higher volatility implies a wider distribution of possible final portfolio values and lower terminal wealth. Second, this study provides empirical evidence that the functional fixation hypothesis propounded by Hand (1990) holds even after we recognize the claim made by Abarbanell and Lehay (2007). Additionally, this paper provides compelling evidence that studies examining the emphasis of alternative earnings metrics on stock return responses should consider the impact of the fourth quarter because most write-offs and special items are recognized in the fourth quarter (Bradshaw \& Sloan, 2002).

In this paper, we use a sample of 308 S\&P500 firms for the period from 2000:Q1 - 2006:Q3. ${ }^{1}$ In this particular sample, our results show that investors following S\&P500 stocks: (i) respond more to pro forma earnings than to GAAP earnings (evident from the earnings response coefficients); (ii) respond to an emphasis on pro forma earnings in earnings press releases; and (iii) are fixated on pro forma earnings.

The remainder of this paper is organized as follows: Section 2 describes the data used and methodology employed. Section 3 presents and explains the empirical results. Section 4 concludes.

\section{Data and methodology}

The final sample used in this study consists of 27 quarters of data for 308 S\&P500 companies. We include only those firms in our sample for which at least 16 
quarters of observations are available. Table 1 presents our sample selection criteria.

Daily price and volume data for the S\&P500 constituents are obtained from Price-Data for the sample period from 2000:Q1 - 2006:Q3. Quarterly GAAP earnings per share data are collected from the Compustat North America database (Compustat item 19 for quarterly data). Quarterly Street earnings per share, median earnings forecasts, and the number of analysts following a firm are collected from IBES via WRDS. To reduce the influence of stale information, only the latest median forecasts around the earnings announcement days are used. Earnings release dates are collected from Earnings.com and are double-checked against official company websites (or IBES report dates are used if the earnings release dates are not available from the company websites). Firm size (market value of equity) data are collected from Compustat.

We collect earnings press releases from companyspecific websites or from Factiva. Street earnings issued by IBES are used as a proxy for pro forma earnings to examine the manipulative intention of firms for two reasons: (i) pro forma earnings are often equal to Street earnings. Bhattacharya et al. (2003) document that IBES actual earnings equal pro forma earnings for 65 percent of their sample; and (ii) even if pro forma and Street earnings are not equal, one can argue that Street earnings still captures managers' intention to emphasize. Bradshaw and Sloan (2002) claim that emphasis on Street earnings is originated from firm managers rather than from forecast data providers such as IBES.

\subsection{Strategic emphasis on earnings numbers}

To identify a strategic emphasis on earnings numbers, we follow Hirshleifer and Teoh (2003) in that investors have limited information processing capacity, which results in a less complete evaluation of quarterly earnings press releases. Elliott (2006); Frederickson and Miller (2004) use this notion as the central construct in their experimental study. We look for two types of emphasis in earnings press releases: relative emphasis and absolute emphasis. Considerable difference exists in the prominence given to pro forma versus GAAP earnings in company press releases. Some companies provide a table containing a reconciliation of pro forma to GAAP earnings with details about the amounts excluded from pro forma earnings, which allows the reader to obtain a clear picture of a firm's financial position. Other companies provide a narrative description of what is excluded from pro forma earnings but do not list the amounts for these items. Finally, some companies mention only one earnings number without any immediate reconciliation information. Marques (2010) finds that, even after the approval of Regulation $G$ in 2002, not all S\&P500 firms that disclose a non-GAAP financial measure include a reconciliation in the press release of the quarterly earnings announcement. ${ }^{2}$ Accordingly, when one earnings metric in a press release is emphasized before another, we define it as a relative emphasis. When only GAAP or pro forma earnings are mentioned without any immediate information about exclusions in the same paragraph of a press release, we define it as an absolute emphasis. In addition, if reconciliation is provided in a tabular form in a press release, we consider it a relative emphasis. If a press release contains only a narrative description of exclusions and if the description appears somewhere in the release but not immediately after where the pro forma earnings are mentioned, we consider it an absolute emphasis.

\subsection{Strategic emphasis on earning numbers and stock returns}

Our empirical analysis begins with a regression model where we regress standardized cumulative abnormal returns on earnings surprises, emphasis, and control variables such as the number of analysts following a firm, firm size, and a policy dummy. Firm size and the number of analysts following a firm provide predisclosure information about a firm. Smaller (larger) firms are likely to have less (more) pre-disclosure information, leading to more (less) information revealed by earnings announcements, whereas firms that are followed by more (less) analysts are expected to provide large (small) amounts of firm-specific information. To examine the effects of press emphasis on stock returns, we run separate regressions for each emphasis term. Running separate regressions for each emphasis term reduces the possibility of linear dependence between alternative earnings surprises. The regression model used in this study to examine the impact of a strategic emphasis on stock returns is given below:

$$
\begin{aligned}
S C A R_{i, t}= & \alpha+\beta_{k} E S_{i, t}^{k}+\gamma_{m k} E S_{i, t}^{k} * I_{m} \\
& +\delta_{1} S I Z E_{i, t}+\delta_{2} A N A_{i, t}+\delta_{3} P D+\varepsilon_{i, t}
\end{aligned}
$$


In the above regression model, $S C A R_{i, t}$ is the standardized cumulative abnormal return around the event (earnings announcement) window for firm $i$ in quarter $t$. Defining the event day as $d=0$, we calculate abnormal returns over the event window $(d-1, d+2)$ as $A R_{i, d}=R_{i, d}-\hat{\alpha}_{i}-\hat{\beta}_{i} R_{m, d}$, where $R_{i, d}$ and $R_{m, d}$ are the realized returns for firm $i$ and the S\&P500 on day $d$, respectively, and $\hat{\alpha}_{i}$ and $\hat{\beta}_{i}$ are estimates from the market model using daily data over the period $(d-2, d-126)$ . Next, standardized abnormal returns are calculated as $S A R_{i, d}=A R_{i, d} / S D_{i}$, where $S D_{i}$ is the standard deviation of $A R_{i, d}$. Finally, standardized cumulative ab-

normal returns are calculated as $S C A R_{i, t}=\sum_{d=-1}^{+2} S A R_{i, d}$. $E S_{i, t}^{k}(k=$ pro forma, GAAP $)$ indicates pro forma and GAAP earnings surprises. We define an earnings surprise for a firm as $E S_{i t}=\frac{E_{i, t}-E_{i, t-4}}{P_{i, d-10}}$, where $E_{i, t}$ is the current quarter's actual earnings, $E_{i, t-4}$ is the actu-

al earnings four quarters back and $P_{i, d-10}$ is the share price 10 trading days before the earnings announcement or event date. $I_{m}$ represents four separate indicator variables $(m=1,3$ for $k=$ pro forma, and $m=2,4$ for $k=G A A P$ ) that define four different types of emphasis. The indicator variable $I_{1}$ equals 1 if the first item reported is pro forma earnings and 0 otherwise, and $I_{2}$ equals 1 if the first item reported is GAAP earnings and 0 otherwise. That is, $I_{1}$ and $I_{2}$ capture the relative emphasis on certain earnings metrics. To capture an absolute emphasis on earnings numbers, we use two more indicator variables defined as $I_{3}$, which equals 1 if a press release text emphasizes only Street earnings (without any immediate reconciliation information in the same paragraph) and 0 otherwise, and $I_{4}$, which equals 1 if a press release text contains only GAAP earnings and 0 otherwise. We have omitted firm quarters where Street earnings = GAAP earnings because we conjecture that there will be no intention on the part of managers to emphasize one earning metric over another if Street earnings are equal to GAAP earnings.

Also in Equation (1), SIZE $E_{i, t-1}$ indicates the market value of a firm's equity in the last fiscal quarter, $A N A_{i, t}$ is the number of analysts following a firm, and $P D$ is the policy dummy. Policy changes regarding the use of pro forma earnings in press releases began late in 2001 when the SEC issued cautionary guidance on the use of pro forma information in earnings releases. Accordingly, our policy dummy variable takes a value of 1 for observations after Q1:2002 and 0 otherwise.

In the above model, $\beta_{k}$ represents the earnings response coefficient (ERC) for pro forma (GAAP) earnings and $\gamma_{m k}$, our main coefficient of interest, captures the incremental response to alternative earnings metrics for different levels of emphasis.

\subsection{Strategic emphasis on earnings numbers and return volatility}

To identify the impact of a strategic emphasis on volatility, we regress the realized volatility of returns around the event window on earnings surprises, emphasis, and the control variables, including abnormal trading volume as an extra explanatory variable in addition to the number of analysts following a firm, firm size, and the policy dummy. Trading volume is a well-established proxy for information arrival in the market (Lamoureux \& Lastrapes, 1990; 1994). In addition, trading volume also reflects a lack of consensus among investors. That is, the volume (volatility) reaction to an earnings announcement could be high if there is more disagreement among investors in interpreting the information content of the earnings news. Specifically, we estimate the following regression equation to examine the impact of strategic emphasis on return volatility:

$$
\begin{aligned}
& R V_{i, t}=\alpha+\beta_{k}\left|E S_{i, t}^{k}\right|+\gamma_{m k}\left|E S_{i, t}^{k}\right| I_{m} \\
& +\delta_{1} \operatorname{SIZE}_{i, t-1}+\delta_{2} A N A_{i, t}+\delta_{3} A B V O L_{i, t}+\delta_{4} P D+\varepsilon_{i, t}
\end{aligned}
$$

In the above regression equation, $R V_{i, t}$ is the log of realized volatility of returns around the event (announcement) window for firm $i$ in quarter $t .^{3}$ Similar to $S C A R_{i, t}$ from Equation (1) defining the event day as $d=0$, we calculate realized volatility over the event window $(d-1, d+2)$. We use the log of realized volatility because the distribution of realized volatility is right-skewed, while the distribution of the logarithm of realized volatility is approximately Gaussian (Andersen et al., 2001). Abnormal trading volume ( $\left.A B V O L_{i, t}\right)$ is calculated as the trading volume on the announcement day $\left(\right.$ Volume $_{i, d}$ ) relative to the average trading volume over $d-1$ to $d-5,\left(\right.$ Volume $\left._{i,(d-1, d-5)}\right)$. That is, the abnormal trading volume is calculated as 
$\frac{\text { Volume }_{i, d}}{\text { Volume }_{i,(d-1, d-5)}}$. The remaining variables in Equation (2), $E S_{i, t}^{k}, I_{m}, A N A_{i, t}$, and $P D$ are defined in the previous section in relation to Equation (1). In the above regression model, $\beta_{k}$ is the earnings response coefficient (ERC), and $\gamma_{m k}$ our parameter of interest, captures the impact of emphasis on earnings numbers.

\subsection{Are investors fixated on pro forma earnings?}

To check whether the Abarbanel and Lehavy (2007) claim against the functional fixation hypothesis is confirmed by our data, we keep only those observations in our sample for which both the pro forma and the GAAP earnings exceed the benchmark (earnings for the same quarter in the prior year), and then again subdivide the sample into two groups-one group includes cases where the pro forma earnings exceed the GAAP earnings, and the other group includes cases where the GAAP earnings exceed the pro forma earnings. Then, for each of these three subsets of observations in the sample, we run a robust regression to estimate the following regression model:

$S C A R_{i, t}=\alpha+\beta_{1} E S_{i, t}^{P F}+\beta_{2} E S_{i, t}^{G A A P}+\varepsilon_{i, t}$

where $E S_{i, t}^{P F}$ and $E S_{i, t}^{G A A P}$ indicate pro forma and GAAP earnings surprises for firm $i$ in quarter $t$, respectively. We test the functional fixation hypothesis by comparing the ERCs of two competing earnings numbers. A higher significance of pro forma earnings in the model that directly links inflation of pro forma earnings to market price reaction can establish the hypothesis.

\section{Estimation Results}

Table 2 presents summary information for the dependent and independent variables used in this study. The mean GAAP earnings surprise is slightly higher than that of the pro forma surprise for firms that issued press releases over the sample period.

Table 3 reports the correlation matrix and the $p$ values for the null hypothesis of zero correlation (in parentheses). The lower diagonal of each panel of the table reports the Pearson correlation, and the upper diagonal reports the Spearman rank correlations. The first two columns and rows show the correlations be- tween the dependent and independent variables. For firm-issued press releases, a pro forma surprise is significantly correlated with returns, but a GAAP surprise is only significantly correlated with returns in case of the Spearman rank correlation. A stronger market reaction to pro forma earnings than GAAP earnings indicates that investors prefer to rely on pro forma numbers to make their investment decisions. However, pro forma and GAAP surprises are negatively related with 4-day realized volatility, with no specific pattern in terms of statistical significance.

We estimate the models in Equations (1) and (2) running pooled regressions. ${ }^{4}$ Dependence in pooled data may arise when (i) residuals are correlated across quarters for a given firm or (ii) residuals for a given quarter are correlated across different firms. When errors are correlated, Ordinary Least Squares (OLS) is still consistent but is biased and typically suggests that standard errors are much too small (Cochrane, 2005). To ensure that the standard errors are conservative relative to alternative estimation techniques, we estimate the models using pooled OLS with standard errors clustered by calendar quarter, by firm and by White standard errors. We find that standard errors clustered by calendar quarters are on average larger than standard errors clustered by firm or by White standard errors. This indicates the presence of a time effect in the data (Petersen, 2009).

Table 4 reports the impact of a relative and an absolute emphasis in company earnings press releases. Although both ERCs for pro forma and GAAP earnings are positively related with contemporaneous returns, only the ERC for pro forma earnings is significant, which indicates that S\&P500 investors consider pro forma earnings to be more value relevant. Our results show that relative emphasis, i.e., highlighting one earnings metric over another, does not affect the S\&P500 returns around earnings announcements days. However, S\&P500 returns respond positively to absolute emphasis, i.e., they respond to earnings announcements when only pro forma earnings are mentioned in the text without any immediate reconciliation information in the same paragraph of the release.

The point estimate of $\gamma_{m k}$ suggests that, for the median value of an earnings surprise of 0.001 (Table 2), the incremental effect of an emphasis on standardized cumulative abnormal returns around the earnings announcement 
Table 2. Descriptive statistics

\begin{tabular}{|c|c|c|c|c|c|c|c|}
\hline & $S C A R$ & $R V$ & $E S^{P F}$ & $E S^{G A A P}$ & ANA & SIZE & $A B V O L$ \\
\hline Mean & 0.21 & -6.16 & 0.00 & 0.001 & 15 & 9.36 & 0.46 \\
\hline Median & 0.26 & -6.16 & 0.001 & 0.001 & 14 & 9.21 & 0.41 \\
\hline SD & 3.01 & 1.37 & 0.01 & 0.136 & 6.5 & 1.09 & 0.53 \\
\hline P1 & -7.50 & -9.34 & -0.06 & -0.113 & 3 & 7.34 & -0.68 \\
\hline P5 & -4.15 & -8.34 & -0.01 & -0.027 & 5 & 7.86 & -0.30 \\
\hline P10 & -2.91 & -7.86 & -0.005 & -0.014 & 7 & 8.11 & -0.15 \\
\hline P25 & -1.49 & -7.07 & 0.00 & -0.004 & 10 & 8.56 & 0.10 \\
\hline P75 & -1.83 & -5.27 & 0.003 & 0.005 & 19 & 9.92 & 0.75 \\
\hline P95 & 4.41 & -3.93 & 0.01 & 0.025 & 27 & 11.5 & 1.43 \\
\hline P99 & 7.87 & -2.90 & 0.03 & 0.105 & 32 & 12.5 & 1.96 \\
\hline
\end{tabular}

Notes:

SCAR is the standardized cumulative abnormal return cumulated over four days surrounding the earnings announcement, $R V$ is the log of 4-day realized volatility (around the earnings announcement), $E^{S P F}$ and $E S^{G A A P}$ are pro forma and GAAP earnings surprises, respectively, ANA is the number of analysts following a firm, SIZE is the log of the market value of a firm's equity, and $A B V O L$ is the log of abnormal volume (the ratio of trading volume on the day of an earnings announcement and the average trading volume of the previous 5 days). The sample consists of 5522 observations.

Table 3. Correlation matrix

\begin{tabular}{|c|c|c|c|c|c|c|c|}
\hline & $S C A R$ & $R V$ & $E S^{P F}$ & $E S^{G A A P}$ & ANA & SIZE & $A B V O L$ \\
\hline$S C A R$ & 1.00 & $\begin{array}{l}0.012 \\
(0.37)\end{array}$ & $\begin{array}{l}0.073 \\
(0.00)\end{array}$ & $\begin{array}{c}0.06 \\
(0.00)\end{array}$ & $\begin{array}{c}-0.025 \\
(0.06)\end{array}$ & $\begin{array}{c}-0.011 \\
(0.42)\end{array}$ & $\begin{array}{r}-0.022 \\
(0.09)\end{array}$ \\
\hline$R V$ & $\begin{array}{l}0.007 \\
(0.58)\end{array}$ & 1.00 & $\begin{array}{r}-0.021 \\
(0.11)\end{array}$ & $\begin{array}{c}-0.024 \\
(0.08)\end{array}$ & $\begin{array}{l}0.053 \\
(0.00)\end{array}$ & $\begin{array}{c}-0.207 \\
(0.00)\end{array}$ & $\begin{array}{l}0.173 \\
(0.00)\end{array}$ \\
\hline$E S^{P F}$ & $\begin{array}{l}0.033 \\
(0.01)\end{array}$ & $\begin{array}{c}-0.086 \\
(0.00)\end{array}$ & 1.00 & $\begin{array}{c}0.00 \\
(0.56)\end{array}$ & $\begin{array}{l}0.085 \\
(0.00)\end{array}$ & $\begin{array}{l}0.058 \\
(0.00)\end{array}$ & $\begin{array}{l}0.035 \\
(0.01)\end{array}$ \\
\hline$E S^{G A A P}$ & $\begin{array}{l}0.003 \\
(0.84)\end{array}$ & $\begin{array}{c}-0.004 \\
(0.74)\end{array}$ & $\begin{array}{r}-0.031 \\
(0.02)\end{array}$ & 1.00 & $\begin{array}{l}0.057 \\
(0.00)\end{array}$ & $\begin{array}{c}-0.002 \\
(0.86)\end{array}$ & $\begin{array}{l}0.012 \\
(0.37)\end{array}$ \\
\hline ANA & $\begin{array}{c}-0.025 \\
(0.07)\end{array}$ & $\begin{array}{l}0.058 \\
(0.00)\end{array}$ & $\begin{array}{l}0.021 \\
(0.12)\end{array}$ & $\begin{array}{l}0.019 \\
(0.16)\end{array}$ & 1.00 & $\begin{array}{c}0.45 \\
(0.00)\end{array}$ & $\begin{array}{r}-0.027 \\
(0.05)\end{array}$ \\
\hline SIZE & $\begin{array}{c}-0.013 \\
(0.35)\end{array}$ & $\begin{array}{l}0.191 \\
(0.00)\end{array}$ & $\begin{array}{l}0.066 \\
(0.00)\end{array}$ & $\begin{array}{c}-0.003 \\
(0.83)\end{array}$ & $\begin{array}{l}0.438 \\
(0.00)\end{array}$ & 1.00 & $\begin{array}{r}-0.019 \\
(0.16)\end{array}$ \\
\hline$A B V O L$ & $\begin{array}{c}-0.049 \\
(0.00)\end{array}$ & $\begin{array}{l}0.207 \\
(0.00)\end{array}$ & $\begin{array}{l}0.035 \\
(0.01)\end{array}$ & $\begin{array}{l}0.003 \\
(0.83)\end{array}$ & $\begin{array}{c}-0.033 \\
(0.01)\end{array}$ & $\begin{array}{c}-0.026 \\
(0.05)\end{array}$ & 1.00 \\
\hline
\end{tabular}

Notes:

The Pearson (Spearman) correlation is shown below (above) the diagonal, and p -values for the null hypothesis of zero correlation are in parentheses. SCAR is the standardized cumulative abnormal return cumulated over four days surrounding the earnings announcement, $R V$ is the log of 4-day realized volatility (around the earnings announcement), ES $S^{P F}$ and $E S^{G A A P}$ are pro forma and GAAP earnings surprises, respectively, ANA is the number of analysts following a firm, SIZE is the log of the market value of a firm's equity, and $A B V O L$ is the log of abnormal volume (the ratio of trading volume on the day of an earnings announcement and the average trading volume of the previous 5 days.) The sample consists of 5522 observations. 
Table 4. Impact of strategic earnings emphasis on stock returns.

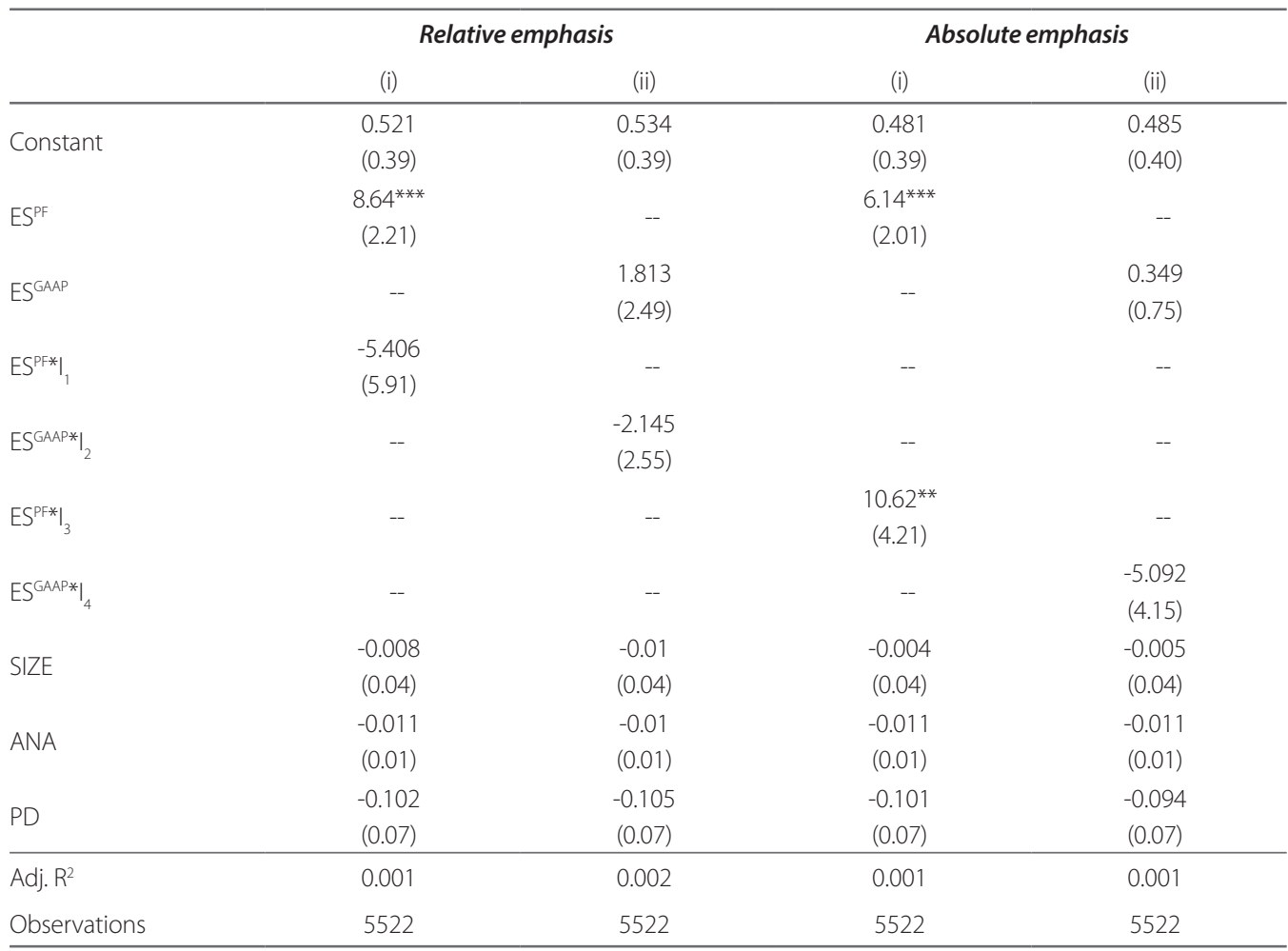

Notes:

This table reports the results for the following regression model:

$S C A R_{i, t}=\alpha+\beta_{k} E S_{i, t}^{k}+\gamma_{m k} E S_{i, t}^{k} * I_{m}+\delta_{1} S I Z E_{i, t-1}+\delta_{2} A N A_{i, t}+\delta_{3} P D+\varepsilon_{i, t}$ where SCAR is the 4-day standardized cumulative abnormal return, $E S^{k}(k=P F, G A A P)$ indicates pro forma and GAAP earnings surprises, respectively, $I_{m}(m=1,3$ for $k=$ pro forma, and $m=2,4$ for $k=G A A P)$ represents indicator variables used to quantify emphasis on earnings numbers, SIZE is the log of the market value of a firm's equity in the last quarter, ANA is the number of analysts following a firm, and PD is the policy dummy variable (to capture the impact of policy changes) that takes a value of 1 for observations after 2002:Q1 and 0 otherwise. Standard errors clustered by calendar quarters are in parentheses.

** significant at $5 \%$ level, ${ }^{* * *}$ significant at $1 \%$ level.

date is 0.01062 (approximately $1.10 \%$ ). This evidence supports the limited attention theory of Hirshleifer and Teoh (2003) and the functional fixation hypothesis of Hand (1990) that investors respond to an emphasis on pro forma earnings because they pay less attention to the appropriateness of the accounting procedures that produce accounting numbers. This result also supports the empirical evidence obtained by Bhattacharya et al. (2003), Brown and Sivakumar (2003), and in experimental studies such as those of Elliott (2006) and Frederickson and Miller (2004) that the market responds more to pro forma earnings than to GAAP earnings. However, the control variables included in the regression between press emphasis and standardized cumulative abnormal returns are not significant at standard significance levels.

Table 5 reports the results for the regression of press emphasis on realized volatility around earnings announcement days. Both pro forma and GAAP surprises are significant and have a positive impact on volatility. Among the four emphasis variables, only the case where pro forma earnings are reported ahead of GAAP earnings in the press release has a significant positive impact on volatility. The results show that when pro forma earnings are emphasized before 
Table 5. Impact of strategic earnings emphasis on return volatility.

\begin{tabular}{|c|c|c|c|c|}
\hline & \multicolumn{2}{|c|}{ Relative emphasis } & \multicolumn{2}{|c|}{ Absolute emphasis } \\
\hline & (i) & (ii) & (i) & (ii) \\
\hline Constant & $\begin{array}{c}-3.568^{* * *} \\
(0.03)\end{array}$ & $\begin{array}{c}-3.424^{* * *} \\
(0.31)\end{array}$ & $\begin{array}{c}-3.595^{* * *} \\
(0.30)\end{array}$ & $\begin{array}{c}-3.407^{* * *} \\
(0.31)\end{array}$ \\
\hline$\left|E S^{P F}\right|$ & $\begin{array}{l}9.09 * * * \\
(1.24)\end{array}$ & -- & $\begin{array}{c}10.57^{* * *} \\
(1.47)\end{array}$ & -- \\
\hline $\mid$ ESGAAP $\mid$ & -- & $\begin{array}{c}1.560^{* * *} \\
(0.40)\end{array}$ & -- & $\begin{array}{c}0.595^{* * *} \\
(0.17)\end{array}$ \\
\hline$\left.\left|\mathrm{ES}^{\mathrm{PF}}\right|^{*}\right|_{1}$ & $\begin{array}{c}9.981^{* *} \\
(4.93)\end{array}$ & -- & -- & -- \\
\hline $\mid$ ES GAAP $\left.^{*}\right|_{2}$ & -- & $\begin{array}{l}-0.34 \\
(0.55)\end{array}$ & -- & -- \\
\hline$\left.\left|E S^{P F}\right|^{*}\right|_{3}$ & -- & -- & $\begin{array}{l}4.795 \\
(3.52)\end{array}$ & -- \\
\hline $\mid$ ES GAAP $\left.^{*}\right|_{4}$ & -- & -- & -- & $\begin{array}{l}0.324 \\
(0.28)\end{array}$ \\
\hline SIZE & $\begin{array}{c}-0.31^{* * *} \\
(0.04)\end{array}$ & $\begin{array}{c}-0.321^{* * *} \\
(0.04)\end{array}$ & $\begin{array}{c}-0.307^{* * *} \\
(0.04)\end{array}$ & $\begin{array}{c}-0.321^{* * *} \\
(0.04)\end{array}$ \\
\hline ANA & $\begin{array}{c}0.04^{* * *} \\
(0.01)\end{array}$ & $\begin{array}{c}0.04^{* * *} \\
(0.01)\end{array}$ & $\begin{array}{c}0.04^{* * *} \\
(0.01)\end{array}$ & $\begin{array}{c}0.04^{* * *} \\
(0.01)\end{array}$ \\
\hline ABVOL & $\begin{array}{c}0.167^{* * *} \\
(0.04)\end{array}$ & $\begin{array}{c}0.603^{* * *} \\
(0.05)\end{array}$ & $\begin{array}{c}0.615^{* * *} \\
(0.04)\end{array}$ & $\begin{array}{c}0.604^{* * *} \\
(0.05)\end{array}$ \\
\hline PD & $\begin{array}{c}-0.825^{* * *} \\
(0.13)\end{array}$ & $\begin{array}{c}-0.818^{* * *} \\
(0.13) \\
\end{array}$ & $\begin{array}{c}-0.816^{* * *} \\
(0.13) \\
\end{array}$ & $\begin{array}{c}-0.822^{* * *} \\
(0.13)\end{array}$ \\
\hline Adj. $R^{2}$ & 0.18 & 0.17 & 0.17 & 0.17 \\
\hline Observations & 5522 & 5522 & 5522 & 5522 \\
\hline
\end{tabular}

Notes:

This table reports the results for the following regression model:

$R V_{i, t}=\alpha+\beta_{k}\left|E S_{i, t}^{k}\right|+\gamma_{m k}\left|E S_{i, t}^{k}\right| *_{m}+\delta_{1} S I Z E_{i, t-1}+\delta_{2} A N A_{i, t}+\delta_{3} A B V O L_{i, t}+\delta_{4} P D+\varepsilon_{i, t}$ where $R V$ is the log of 4-day realized volatility, $E^{k}(k=P F, G A A P)$ indicates pro forma and GAAP earnings surprises, respectively, $I_{m}(m=1,3$ for $k=$ pro forma, and $m=2,4$ for $k=G A A P$ ) represents indicator variables used to quantify emphasis on earnings numbers, SIZE is the log of the market value of a firm's equity in the last quarter, $A N A$ is the number of analysts following a firm, $A B V O L$ is the log of abnormal volume around the announcement day, and PD is the policy dummy variable (to capture the impact of policy changes) that takes a value of 1 for observations after 2002:Q1 and 0 otherwise. Standard errors clustered by calendar quarters are in parentheses.

** significant at 5\% level, ${ }^{* * *}$ significant at $1 \%$ level.

GAAP earnings, return volatility increases. Given the median value of an earnings surprise in Table 2, our point estimate of $\gamma_{m k}$ suggests that an emphasis on pro forma earnings over GAAP earnings increases the log value of realized volatility around the earnings announcement date by approximately 0.01 . This result supports our conclusion about the return impact of emphasis and bolsters our finding that inves- tors following the S\&P500 companies respond mainly to a pro forma earnings emphasis. Firm size (SIZE) shows a negative relationship with realized volatility around earnings announcement days. This result supports the notion that large firms have lower information asymmetry around earnings announcements. The number of analysts following a firm is positively related with return volatility. That is, firms 
Table 6. investors fixated on pro forma earnings?

\begin{tabular}{|c|c|c|c|}
\hline \multicolumn{4}{|c|}{$\begin{array}{c}\text { When EPS } \\
\text { greater than the benchmark }\end{array}$} \\
\hline & $\begin{array}{l}\text { Full sample } \\
\text { (i) }\end{array}$ & $\operatorname{EPS}_{\text {Pro forma }}>E P S_{\text {GAAP }}$ & $\begin{array}{c}\mathrm{EPS}_{\text {GAAP }}>\mathrm{EPS}_{\text {Pro forma }} \\
\text { (iii) }\end{array}$ \\
\hline Constant & $\begin{array}{c}0.194^{* * *} \\
(0.06)\end{array}$ & $\begin{array}{r}-0.093 \\
(0.32)\end{array}$ & $\begin{array}{l}0.276^{* * *} \\
(0.07)\end{array}$ \\
\hline$E S^{P F}$ & $\begin{array}{c}60.24^{* * *} \\
(16.9)\end{array}$ & $\begin{array}{c}109.4^{* * *} \\
(32.9)\end{array}$ & $\begin{array}{c}51.67^{* *} \\
(20.7)\end{array}$ \\
\hline ES GAAP & $\begin{array}{l}-4.948 \\
(8.41)\end{array}$ & $\begin{array}{l}-24.09 \\
(30.6)\end{array}$ & $\begin{array}{l}-5.24 \\
(9.35)\end{array}$ \\
\hline Adj. $R^{2}$ & 0.005 & 0.02 & 0.003 \\
\hline Observations & 2624 & 584 & 2040 \\
\hline
\end{tabular}

Notes:

This table reports the results for the following regression model:

$S C A R_{i, t}=\alpha+\beta_{1} E S_{i, t}^{P F}+\beta_{2} E S_{i, t}^{G A A P}+\varepsilon_{i, t}$

where SCAR is the 4-day standardized cumulative abnormal return, and ESPF and ESGAP indicate pro forma and GAAP earnings surprises, respectively. Column (i) reports the results for the full sample when both pro forma and GAAP earnings exceed the benchmark (earnings for the same quarter in the prior year), Column (ii) reports the results for the sample when both pro forma and GAAP earnings exceed the benchmark and pro forma is higher than GAAP earnings, and Column (iii) reports the results for the sample when both pro forma and GAAP earnings exceed the benchmark and GAAP is higher than pro forma earnings.

${ }^{* *}$ significant at 5\% level, ${ }^{* * *}$ significant at 1\% level.

with more analysts (ANA) following them are expected to produce a large amount of both financial and non-financial information. Therefore, the number of analysts following a firm is expected to reduce volatility. However, if analysts' forecast dispersion around the earnings announcement day increases, volatility may also increase. Abnormal volume ( $A B V O L)$ has a significant and positive relationship with volatility, which suggests that any unexpected news (good or bad) is followed by above-average trading activity as the market seeks out a new equilibrium. However, the strength of this volume-volatility depends on the degree of homogeneity in the interpretation of the news. The policy dummy included in the regression $(P D)$ captures the fundamental change in pro forma reporting incentives as well as investors' perceptions about pro forma disclosures. Our results indicate that such changes in disclosure policy have significantly reduced volatility related with quarterly earnings announcements. This result may be the outcome of an improvement in the quality of information included in earnings press releases (Yi, 2012).

Our regression results reported in Table 6 show that investors respond to pro forma earnings when both the earnings exceed their benchmark and when either pro forma earnings are greater than GAAP earnings or GAAP earnings are greater than pro forma earnings. This result suggests that S\&P500 investors are fixated on pro forma earnings and thus supports the theories regarding investors' inattention to the use of an appropriate accounting procedures and their limited attention in processing earnings information (Hirshleifer \& Teoh, 2003; Hand, 1990). However, this result does not support the claim of Abarbanell and Lehavy (2007) that the large differences between Street and GAAP earnings supplied by forecast data providers may lead 
a researcher to wrongly support the notion that investors are fixated on Street earnings.

\subsection{Robustness Checks}

\subsubsection{Impact of extreme observations}

To check whether our results are robust to extreme observations, we re-estimate the regression models in Equation (1) and Equation (2) using robust regression. Our results (not tabulated) for emphasis on competing earnings numbers by companies remain similar to our pooled OLS results. That is, we find that investors respond to an absolute pro forma earnings emphasis in the case of returns regression and respond to a relative emphasis on pro forma earnings in the case of volatility regression.

\subsubsection{Impact of the fourth quarter}

Fourth quarter earnings differ systematically from other quarter's earnings (Mendenhall \& Nichols, 1988; Bradshaw \& Sloan, 2002). Bradshaw and Sloan (2002) find that growth calculations based on Street earnings per share are statistically larger than those based on GAAP earnings per share. This difference is especially pronounced in the fourth quarter, where mean growth based on Street earnings per share is approximately three times that calculated based on GAAP earnings per share. Managerial opportunism and accounting year-end adjustments are considered the main reasons for such a difference. From the viewpoint of a strategic emphasis in earnings numbers, the fourth quarter is unique because discretionary write offs and special items are recognized more in the fourth quarter than in other quarters. To account for the unique nature of the fourth quarter and to examine whether it affects our empirical results, we rerun regression models in Equation (1) and Equation (2) excluding the fourth quarter observations from the sample.

Our results (not tabulated) show that when re-running the regressions without fourth quarter observations, the significant return response to an absolute emphasis on pro forma earnings vanishes, whereas the relationship between volatility and pro forma earnings emphasis becomes weak in terms of statistical significance. However, the return and volatility response to pro forma and GAAP surprises remains significant. This result supports the claim of Bradshaw and Sloan (2002) that the fourth quarter plays a role in results that provide statistical support for a greater investor reaction to pro forma earnings.

\section{Summary and Conclusion}

When preparing pro forma earnings statements, managers generally exclude nonrecurring transitory items that are believed to be less relevant to normal ongoing company operations. Because pro forma statements are neither audited nor subject to direct scrutiny by the SEC, companies effectively enjoy the discretion to exclude anything from these financial statements that they believe can affect the accuracy of their financial outlook. Although proponents of pro forma estimates argue that these numbers provide a better idea about a company's actual earnings performance, they leave open the possibility of opportunistically omitting certain important expense items to overstate a company's financial performance. One of the most controversial uses of pro forma statements is to release pro forma numbers to market participants before the audited GAAP financial statements are made available. Early releases of pro forma numbers without a clear-cut reconciliation of pro forma to GAAP numbers can encourage investors to make investment decisions on the basis of incomplete information.

Using a sample of 308 firms from the S\&P500 for the period from 2000:Q1 - 2006:Q3, we find that the investors do respond to an emphasis on pro forma earnings in earnings press releases, and they are not as attentive to judging whether exclusions from pro forma statements are appropriate when making investment decisions. Our results also show that when pro forma earnings are emphasized before GAAP earnings, stock return volatility increases in the period surrounding the earnings disclosure in the press releases. These results are robust to extreme observations in the sample.

We also provide empirical evidence that nullifies the claim of Abarbanell \& Lehavy (2007) that the reported incremental investor response to Street earnings is in fact driven by the high frequency of large differences between Street and GAAP numbers. Using robust regression estimation, we show that the functional fixation hypothesis propounded by Hand (1990) still holds even if we recognize the claim made by Abarbanell \& Lehay (2007). 
When fourth quarter observations are dropped from our estimation, return response to an absolute emphasis on pro forma earnings becomes insignificant, and the relationship between volatility and a pro forma earnings emphasis becomes weak in terms of statistical significance. However, the return and volatility response to pro forma and GAAP surprises remains significant.

The results of this paper may have implications for market regulators and policy makers in that they may help to formulate rules to increase the quality and quantity of information by defining what and how information should be presented to investors. If small investors respond to managers' strategic behavior in terms of an emphasis on earnings numbers, policy makers should take action by changing the present policy or by introducing a new policy to control the adverse effect of a strategic emphasis by firms. However, such policy measures may not work in the case of judgmental errors made by rational investors. Therefore, in addition to devising an appropriate policy response, investors also need to be educated (for example, through information campaigns) so that they can identify such strategic behavior of companies and make more rational investment decisions.

\section{References}

Abarbanell, J. S., \& Lehavy, R. (2007). Letting the 'tail wag the dog': The debate over GAAP versus Street earnings revisited. Contemporary Accounting Research, 24 (3), 675-723.

Andersen, T. G., Bollerslev, T., Diebold, F. X. \& Ebens, H. (2001). The distribution of realized stock return volatility. Journal of Financial Economics, 61 (1), 43-76.

Bergstresser, D., \& Philippon, T. (2006). CEO incentives and earnings management. Journal of Financial Economics, 80 (3), 511-529.

Bhattacharya, N., Black, E. L., Christensen, T. E., \& Larson, C. R. (2003). Assessing the relative informativeness of pro forma earnings and GAAP operating earnings. Journal of Accounting and Economics, 36 (1-3), 285-319.

Bhattacharya, N., Black, E. L, Christensen, T. E., \& Mergenthaler, R. D. (2004). Empirical evidence on recent trends in pro forma reporting. Accounting Horizons, 18 (1), 27-43.
Bloomfield, R. (2002). The 'Incomplete Revelation Hypothesis' and financial reporting. Accounting $\mathrm{Ho}$ rizons, 16 (3), 233-243.

Bowen, R. M., Davis, A. K., Matsumoto, D. A. (2005). Emphasis on pro forma versus GAAP earnings in quarterly press releases: determinants, SEC intervention, and market reactions. The Accounting Review, 80 (4), 1011-1038.

Bradshaw, M., \& Sloan, R. (2002). GAAP versus the Street: An empirical assessment of two alternative definitions of earnings. Journal of Accounting Research, 40 (1), 41-66.

Brown, L. D., \& Sivakumar, K. (2003). Comparing the value relevance of two operating income measures. Review of Accounting Studies, 8 (4), 561-572.

Cochrane, J. H. (2005). Asset Pricing (Revised edition). New Jersey, NJ: Princeton University Press

Doyle, J. T., Jennings, J. N., \& Soliman, M. T. (2013). Do managers define non-GAAP earnings to meet or beat analyst forecasts? Journal of Accounting and Economics, 56 (1), 40-56.

Elliott, W. B. (2006). Are investors influenced by pro forma emphasis and reconciliations in earnings announcements? The Accounting Review, 81 (1), 113-133.

Frederickson, J. R., \& Miller, J. S. (2004). The effect of pro forma earnings disclosures on analysts' and nonprofessional investors' equity valuation judgments. The Accounting Review, 79 (3), 667-686.

Hand, J. R. M. (1990). A test of the extended functional fixation hypothesis. The Accounting Review, 65 (4), 740-763

Hirshleifer, D., \& Teoh, S. H. (2003). Limited attention, information disclosure, and financial reporting. Journal of Accounting and Economics, 36 (1-3), 373-386.

Kim, O., \& Verrecchia, R. E. (1994). Market liquidity and volume around earnings announcements. Journal of Accounting and Economics, 17 (1-2), 41-67.

Lamoureux, C., \& Lastrapes W. D. (1990). Heteroskedasticity in stock return data: Volume versus GARCH effects. Journal of Finance, 45 (1), 221229.

Lamoureux, C., \& Lastrapes W. D. (1994). Endogenous trading volume and momentum in stock-return volatility. Journal of Business and Economic Statistics, 12 (2), 253-260. 
Libby, R., Bloomfield, R., \& Nelson, M. W. (2002). Experimental research in financial accounting. Accounting, Organizations and Society, 27 (8), 775-810.

Lougee, B. A., \& Marquardt, C. A. (2004). Earnings informativeness and strategic disclosure: An empirical examination of 'pro forma' earnings. The Accounting Review, 79 (3), 769-795.

Marques, A. (2010). Disclosure strategies among S\&P 500 firms: Evidence on the disclosure of nonGAAP financial measures and financial statements in earnings press releases. British Accounting Review, 42 (2), 119-131.

Mendenhall, R., \& Nichols, W. (1988). Bad news and differential market reactions to announcements of earlier-quarters versus fourth-quarter earnings. Journal of Accounting Research, 26 (Suppl.), 63-86.

Petersen, M. A. (2009). Estimating standard errors in finance panel data sets: Comparing approaches. The Review of Financial Studies, 22 (1), 435-480.

Yi, H. (2012). Has Regulation G improved information quality of non-GAAP earnings disclosures? Seoul Journal of Business, 18 (2), 95-145.

\section{Endnotes}

1 The sample period of 2000 to 2006 is chosen to increase the number of firms included in the study. Considering the scarcity of firm-specific data from the source we use, we could not go back beyond 2000. In addition, we have not extended the study period beyond 2006 because with the introduction of Regulation $G$ in early 2003, the number of firms using a strategic emphasis has decreased, although it has not stopped entirely (Marques, 2010).

2 The SEC has adopted Regulation G (Reg G) effective from March 2003 that is applicable to public companies' disclosures of certain financial information that is presented on the basis of methodologies other than GAAP. This regulation requires a reconciliation of non-GAAP to GAAP measures in all public announcements made by a firm.

3 Assuming that returns are zero mean and have zero autocorrelation, realized volatility of returns is estimated as the sum of daily squared returns over the event window $(d-1, d+2)$.

4 A primary reason that we use pooled regression analysis is to capture not only the variation that emerges through time or space but also to capture the variation of these two dimensions simultaneously. Moreover, because cross-sectional variation is usually greater than time-series variation, the pooled estimates are expected to have the desirable property of being derived from a wider space of variation than estimates based solely on timeseries data.

\section{Acknowledgements}

The authors would like to thank the editor and two anonymous reviwers for their comments that help improve the manuscript. We are grateful for valuable comments and suggestions received from Madhu Veeraraghavan, Bala Balachandran, Nilabhra Bhattacharya, Sugato Chakravarty, George Tanewski, Dan Dhaliwal, Michael Dempsey, Kim Langfield-Smith, Vijaya Marisetty, Alan Ramsay, and the participants of 2006 AFFANZ doctoral students consortium and the Finance Brown Bag Series at Monash University. 
